\title{
Performance, Mental effort and Efficiency Of Multimedia-Based Discovery Learning in Mathematics Learning
}

\author{
Jarnawi Afgani Dahlan \\ Departement of Mathematics Education \\ Universitas Pendidikan Indonesia \\ email: jarnawi@upi.edu
}

\begin{abstract}
Design of learning development now is much more motivated by the importance of student-centered learning. In other words, students must be active in learning. Learning activity according to [8] consists of two parts: active cognitively and active behaviorally. The combination of both will affect the emergence of meaningful learning. According to [8], the meaningful learning process will emerge when students have high activity in the cognitive, especially if supported by higher activity in the behavior. Thus, the first focus that should be the concern of teachers is how to bring the cognitive activity of the students. Whereas the importance of the cognitive activity, the curriculum of 2013 recommended models based on the student's activity, such as Problem Based Learning, Discovery Learning and Project Based Learning. However, the activity of students in the class necessarily considers its efficiency. Efficiency is based on two things, mental effort and performance. Two learners may get a same performance score but with a very different mental effort. The combination of mental effort and performance measurements can provide an estimate on the relative efficiency condition of learning. It is for that this study attempts to examine how the relative efficiency in the discovery learning model through multimedia.
\end{abstract}

Keywords- meaningful learning; discovery learning models; multimedia; performance; mental effort; efficiency

\section{INTRODUCTION}

Constructivist learning theory has a lot to give effect to changes in the development of learning design. The changes are marked by a shift in focus of the learning activities from teachers to students. Student learning center has become adage that sufficiently massive as one jargon in the change of constructivists. As a result, innovations that emerged in the development of learning model has always been associated with active learning.

Designing the active student-focused learning starts from how teacher designs the learning. Because a teacher started thinking about learning through three stages. As proposed by [15] that the process of teacher's thinking in the learning context occurs in three phases: before the learning, during the learning takes place, and after learning. The teacher's planning before the learning process will create a situation that can be a starting point for the learning process of their students. It is that why the planning becomes an important thing done by the teacher.

The involvement of the students actively here is not always active physically, but can also be interpreted as active mentally. Table I presents two types of active learning by [8] and the impact on the meaningfulness in learning.

From Table I, it appears that meaningful learning does not depend on active physically, but it's very dependent on the cognitive activity or mental activity of students during learning.

TABLE I. Two TyPES Of Active LEARNING

\begin{tabular}{|c|c|c|c|}
\hline & & \multicolumn{2}{|c|}{ Cognitive Activity } \\
\hline & & Low & High \\
\hline 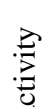 & 艿 & $\begin{array}{l}\text { not increase the yield } \\
\text { of meaningful } \\
\text { learning }\end{array}$ & $\begin{array}{l}\text { increase the yield of } \\
\text { meaningful learning }\end{array}$ \\
\hline :00 & 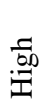 & $\begin{array}{l}\text { not increase the yield } \\
\text { of meaningful } \\
\text { learning }\end{array}$ & $\begin{array}{l}\text { increase the yield of } \\
\text { meaningful learning }\end{array}$ \\
\hline
\end{tabular}

Making the students involved in active mentally during the learning is not easy. Therefore, teachers as learning planners must able to choose an appropriate learning model for a particular material. Because, basically learning model is a form of learning which is reflected from start to finish typically presented by teachers, in other words learning model is a wrap or frame of the application of an approach, method and technique of learning [3]. This is reinforced by the function of the learning model proposed by [2], namely learning model having a function to provide a direction in designing the learning in order to help learners for achieving various objectives and/or competences.

One model of learning that requires students to be involved mentally active is discovery learning model. The discovery here is not inventing a new thing, but reinvention. Bruner [18] revealed four reasons for using the discovery 
learning:

1. to make an impulse of thought,

2. to develop inner motivation than outer motivation,

3. to learn the way of discovery,

4. to develop thought.

Reviewed from the cognitive result achieved in the learning, according to the research result by [10] it can be known that the discovery learning model is better than the application of interactive demonstration in improving the cognitive learning outcome. In this discovery learning model, teachers give students the chance to try to find themselves a concept, a theory, or a rule that is new knowledge for students through a problem that has been engineered by the teacher. In addition to prepare the engineered problem, the teacher also should be able to advice and direct the students to be able to actively gather some information, compare, categorize, analyze, integrate, reorganize the materials and make conclusions that ultimately became a new knowledge for students.

In addition to select the learning model that is expected to make the students to be active, especially mentally, the teachers as planners all at once designers of learning design must also understand how the process of information processing occurs in the student's brain. This is important because every human being has limitations to be able to process a number of information at a time ,

The processing of information into a new knowledge occurs in the memory of the human brain called as cognitive process. The process according to [6]; [20] involves three types of brain memory: sensory memory, working memory, and long-term memory. There are three processes occurring when the sensory memory receives an information: attention, perception or recognition of patterns and giving a meaning [12]. After gathering the necessary information and ignoring the unnecessary information, the sensory memory system sends the information to the working memory. the entry of information into working memory is marked by the thinking of such information. After it has been organized and given a meaning, this information can then be formed into a new knowledge which will then be stored in long term memory which has an unlimited capacity. If the long-term memory has prior knowledge which is a prerequisite to interpret the information that is being processed in the working memory, then the working memory can easier to process the information into a knowledge, because essentially the working memory has a limited capacity [16]. [16] called it as cognitive load.

Cognitive load contained in the working memory during the learning process according to [17] sourced three things, namely:

1. Intrinsic Cognitive Load, cognitive load depends on the difficulty level of the material being studied.

2. extraneous cognitive load, cognitive load depends on how the presentation of the material being studied, the cognitive load will be higher if the presentation a lot of elements that are irrelevant to the material being studied.
3. Germane Cognitive Load, cognitive load is dependent on cognitive processes in accordance with one's understanding of the material being studied once the construction process knowledge of the material.

To anticipate them according to [1] the learning developed by the teacher must minimize extraneous load, manage the intrinsic load, and seeks to bring germane load. Meanwhile, according to [11] learning will be effective if it is not over-load in the use of mental capacity. Therefore, a good learning design according to the cognitive load theory requires the teacher to adjust the cognitive loads that will be accepted so that students do not experience cognitive overload. Because according to [8] teacher is a cognitive adviser providing a necessary guidance to support cognitive processing on the part of students.

[8] stated that the models of verbal presentation learning has dominated the way we deliver information to others - and their verbal learning has dominated education. In fact, to process information, people have multiple channels where two of them are information-processing through visual and verbal modes. Because the two have a limited capacity, then the use of the two simultaneously will help humans in processing the information. Thus, learning that utilizes visual and verbal channels owned by the students, may be a solution that can make students to be more easily in processing the information. According to [8] the understanding occurs when students can make a meaningful connection/relationship between verbal and visual representations.

The utilization of two channels all at once can be done in the multimedia-aided learning. Because according to Macaulay [13] multimedia can be defined as a combination of texts, images, animations, graphics, sounds and videos, to display information under the computer control. As a result, when a person is using multimedia, it means that he is utilizing a variety of channels that can help to process the information. It is this one powerful reason why multimediaaided learning allegedly more can alleviate the cognitive load of students rather than learning without utilizing multimedia. In addition, the research results by [4] showed that the Multimedia Interactive-aided discovery learning in the learning loop in the Pascal programming language can improve the students' cognitive learning outcomes in the medium category.

One software that can be used to create multimediaaided learning is Microsoft Office Power Point. Microsoft Power Point is a software presentation that can combine images, sounds, graphics, animations, and even videos in a single computer screen.

The [9] stated,

Experimental manipulations such as a particular task or training environments Often do not yield significant effects on performance measures. Combinations of task performance and mental effort scores can be more sensitive to the cognitive costs of training or task environments than are measures of performance or mental effort alone.

Because some studies inspired from Cognitive Load 
Theory does not actually measure the cognitive load. Two learners may get scores the same performance but with a very different mental effort. The combination of mental effort and performance measurement can provide an estimate of the relative efficiency of the condition (condition relative efficiency) learning.

Each learning model has its advantages and disadvantages of each, as well as discovery learning model. According to Bruner [19] discovery learning is the most inefficient possible technique for regaining what has been Gathered over a long period of time. On the basis of the argument [16], this research tries to use multimedia as a learning medium so that is expected to improve the efficiency of discovery learning models.

Based on the above background, we formulate the following research questions:

1. How is the performance of students with multimediaaided discovery learning model and discovery learning model without multimedia?

2. How is the mental effort students with multimediaaided model of discovery learning and discovery learning model without multimedia?

3. Is the use of multimedia-aided model of discovery learning in mathematics learning is more efficient than the discovery learning model without multimedia?

\section{RESEARCH METHOD}

This study assessed the efficiency of the use of discovery learning model by comparing performance and mental effort among groups of media-aided discovery learning model by discovery learning model without multimedia.

Subjects in this study were students one junior high school in Bandung. Selection of students is done by purposive sampling so as not to interfere with the education agenda in schools where research is done with a lot of students in each group is 33 students. The instrument used was the performance test, the mental attitude scale effort and learning tools based on discovery learning models. Measurements made with the instrument performance test based on material taught at the time of the study.

TABLE II. RECAPITULATION OF QUALITY INSTRUMENT OF Performance Test (Reliability: 0.79 (High))

\begin{tabular}{|c|c|c|c|}
\hline Item & $\begin{array}{c}\text { Validity } \\
\text { of item }\end{array}$ & $\begin{array}{c}\text { Discriminating } \\
\text { index }\end{array}$ & $\begin{array}{c}\text { Difficulty } \\
\text { Index }\end{array}$ \\
\hline 1 & 0.676 & 0.578 & 0.600 \\
\hline 2 & 0.599 & 0.489 & 0.494 \\
\hline 3 & 0.834 & 0.761 & 0.547 \\
\hline 4 & 0.688 & 0.659 & 0,544 \\
\hline 5 & 0.905 & 0.894 & 0.600 \\
\hline 6 & 0.676 & 0.578 & 0.600 \\
\hline
\end{tabular}

While mental effort is measured by using the method of Rating Scale Mental Effort (RSME) that has been adapted for use in Indonesia. RSME undimensional is an instrument with seven points of reference in the interval 1-150.

\section{RESULTS AND DISCUSSION}

This research begins with the provision of pre-test performance of students. The results of data processing performance initially, inferentially known that there is no significant difference from the initial performance both groups. Thus, this study started from two groups that have the same initial conditions, so changes occurring from the research results can be concluded as a result of the treatment given

The next stage is the implementation of research by applying a discovery learning model with multimedia, while the other classes are not using multimedia. Multimedia is seen as an effort to minimize the cognitive load of students.

TABLE III. DESCRIPTIVE STATISTICS OF POSTTEST PERFORMANCE

\begin{tabular}{|c|c|c|c|c|}
\hline Class & N & Mean & SMI & $\begin{array}{c}\text { Std. } \\
\text { Deviation }\end{array}$ \\
\hline Experiment & 33 & 65.3333 & 80 & 12.58885 \\
\hline Control & 33 & 58.6667 & 80 & 16.16259 \\
\hline
\end{tabular}

Table III shows that the descriptive performance of the group of students through discovery learning models with multimedia was higher than the group of students through discovery learning without multimedia. In addition, the performance score distribution is not too spread out as in a group of student's discovery learning without multimedia. Thus the conclusion descriptively indicate a difference in student performance between groups with multimedia-aided discovery learning as compared with discovery learning without multimedia.

The results of the study can be seen in the Table IV.

TABLE IV. DESCRIPTIVE STATISTICS OF MENTAL EFFORT SCORE
\begin{tabular}{|c|c|c|c|}
\hline Class & N & Mean & $\begin{array}{c}\text { Std. } \\
\text { Deviation }\end{array}$ \\
\hline Experiment & 33 & 92.4242 & 13.75007 \\
\hline Control & 33 & 99.0606 & 17.67226 \\
\hline
\end{tabular}

Scores of mental effort showed how high thinking efforts by students in the learning process. From the data in Table IV it appears that the average mental effort groups of students with discovery learning without multimedia is much higher as compared with the group of students with multimedia. This discovery learning shows that the role of multimedia appreciable assist students in using their thinking efforts.

The statistical difference over the mental effort turned out very meaningful. It can be seen from the test results via the student's t-test showed that the probability of rejection of the null hypothesis at 0.049 . That is the mental effort students with discovery learning without multimedia significantly higher as compared with the group of students with discovery learning multimedia. These test results provide a confidence that the role of multimedia in discovery learning can reduce the mental effort students significantly.

The next finding in this study is the relative efficiency of multimedia-aided discovery learning by 
discovery learning without multimedia. Descriptive efficiency of two models of learning are as follows.

TABLE V. THE RESULTS OF RELATIVE EFFICIENCY SCORE
\begin{tabular}{|c|c|c|c|}
\hline Class & \multicolumn{2}{|c|}{$\begin{array}{c}\text { The average } \mathbf{z} \\
\text { scores }\end{array}$} & $\begin{array}{c}\text { Efficiency } \\
\text { Score }\end{array}$ \\
\hline Experiment & -0.21 & 0.23 & 0.30 \\
\hline Control & 0.21 & -0.23 & -0.30 \\
\hline
\end{tabular}

From Table V shows that the relative efficiency score for an experimental class and control class respectively are 0.30 and -0.30 . From the score, after $t$ test to see if the experimental class relative efficiency score significantly higher than the control class or not, the result that the relative efficiency of the experimental class score significantly higher than the experimental class. It also shows that students in class experiments obtain mathematics learning using a model of discovery learning-aided multimedia learning outcomes (performance) with higher mental effort (mental effort) that they spend less than the control class learning in the discovery learning model without multimedia. Thus it can be concluded that discovery learning in the mathematics learning using multimedia-aided models are more efficient than mathematics learning using discovery learning model without multimedia.

To see more clearly the efficiency of the two groups, the values in Table 6 above can be described in a coordinate system $\mathrm{R}, \mathrm{P}$ ( $\mathrm{R}=$ mental effort, $\mathrm{P}=$ performance). Score relative efficiency $(E)$ represented by the distance of the point $(\mathrm{R}, \mathrm{P})$ which is perpendicular to the line $\mathrm{E}=0$. The upper left part of the coordinate system $\mathrm{R}, \mathrm{P}$ indicates an increase in efficiency (higher performance in conjunction with a lower mental effort) and the bottom right indicates a decrease in the efficiency (lower performance in conjunction with higher mental effort).

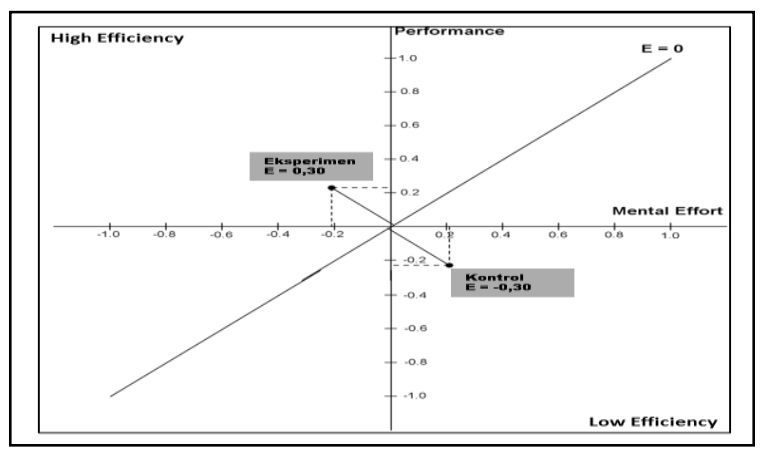

Fig. 1. Relative Efficiency (E) of Two Classes

To strengthen the descriptive results of efficiency differences above, the following are presented the test results of the efficiency scores obtained from both groups. The Table VI shows the results of testing the significance of differences in efficiency between the two groups.

From the Table VI is known that statistical differences in the efficiency of the two groups is very significant learning. From the data processing has been done above can be obtained some information that the performance of students through discovery learning using either the media or with no multimedia effects in pretty good on student's performance, i.e. on average the test results finally in a row 65.3 and 58.67 out of a maximum score of 80 . If the ideal is transformed into a scale of 100 the result was 81.6 and 73.3. These results illustrate that the use of discovery learning model in the study of mathematics sufficient to provide an increase in the students' understanding of mathematical knowledge learned. These results are consistent with the argument that the 2013 curriculum development team by applying Discovery Learning repeatedly to improve the ability of self-discovery of the individual concerned. Use of Discovery Learning, wants to change the condition of passive learning to active and creative. Changing learning teacheroriented to student oriented [5]. The process according to Slavin [14] encourage students to learn independently and problem-solving skills to think, because they have to analyze and manipulate information. The impact was as an advantage for students to learn the material that can achieve a high level of capability and longer lasting because students are involved in the process find him (Marzano in [14]).

TABLE VI. THE DIFFERENCE TEST OF TWO AVERAGE RELATIVE EFFICIENCY SCORES

\begin{tabular}{|c|c|c|c|c|}
\hline & & $\mathbf{t}$ & df & $\begin{array}{c}\text { Sig (2- } \\
\text { tailed) }\end{array}$ \\
\hline $\begin{array}{c}\text { Efiensi } \\
\text { Relatif }\end{array}$ & $\begin{array}{c}\text { Equal variances } \\
\text { assumed }\end{array}$ & 2,584 & 64 & 0.61061 \\
\cline { 2 - 5 } & $\begin{array}{c}\text { Equal variances } \\
\text { not assumed }\end{array}$ & 2,584 & $\begin{array}{r}58.1 \\
33\end{array}$ & 0.61061 \\
\hline
\end{tabular}

If the terms of mental effort, the use of discovery learning model can be said to be too high, ie $92.42(62.62 \%)$ when using multimedia and $99.06(66.05 \%)$ if it is not accompanied by multimedia. When linked to the stages of discovery learning that starts from the stage of filing of the situation until concluded, mental effort undertaken by students is very high. When he was in the 2 nd stage only, students must think the question what is feasible with regard to the situation posed by the teacher. As a result, it is not uncommon students who fail to submit issues, questions irrelevant, and others. Other stages are deemed high enough require mental effort is concluded (generalization). By the time students have to conclude, he must obtain a pattern, do conjecture, after which he will come to the stage of generalization (Marzano in [14]. This process is a process of inductive reasoning, which in theory are classified into high-level thinking.

From the analysis of the efficiency obtained information that the level of efficiency of the discovery of multimedia-based learning are statistically more efficient than the discovery learning without multimedia. These results reinforce the notion Shuler [7] that today's technology has the opportunity to develop attractive learning so as to improve the individual learning and social interaction, as well as more away can improve the efficiency of the institution (school). And also strengthen the argument [8] that the use of multimedia in teaching encourages meaningfulness of learning in students, and have the opportunity to reduce the cognitive load of students. In addition, Tabbers [3] also 
proposed that in many types of multimedia instruction, required the integration of information from different channels, thereby causing no higher cognitive load.

Low cognitive load on a group of media-based presentation of the elements caused by reduced too much in learning. This is as expressed by Mayer and Moreno [3] that the working memory limitations of human being in memory overload can be caused by the presentation of the overloaded elements.

\section{CONCLUSION}

Based on the results described earlier, we conclude:

1. Performance of students with multimedia-aided discovery learning is higher than the performance of students with discovery learning without multimedia

2. Student's mental effort with multimedia-aided discovery learning is lower than the group of students with discovery learning without multimedia.

3. Implementation of multimedia-aided discovery learning model in mathematics learning is more efficient than the discovery learning model without multimedia.

Based on research that has been done and the conclusions obtained, there are some recommendations that can provide the authors with regard to this study, namely:

1. In order to improve the efficiency of discovery learning the teachers would use learning media, especially with multimedia.

2. The use of multimedia must be adapted to the steps in the learning model, as well as in its development must be adapted to the principles of multimedia

3. There is necessarily also another assessment in determining or formulating the classifications of the efficiency quality of a learning model.

4. in the future the studies can also study other variables that can possibly be a parameter in calculating the relative efficiency of a learning model.

\section{Refferences}

[1] Aditomo, A. Cognitive Load Theory and Mathematics Learning : A systematic review. Journal : Anima, Indonesian Psychological Journal, 24(3), hlm. 207-217. 2009.

[2] Harahap, M. B. Model pembelajaran efektif untuk mencapai kompetensi dalam kurikulum 2013. PowerPoint pada presentasi di Universitas Terbuka. 2014.

[3] Herdian. Apa perbedaannya : Model, metode, Strategi, pendekatan dan teknik pembelajaran. [Online]. Diakses dari https://herdy07.wordpress.com/2012/03/17/apa-perbedaannya-modelmetode-strategi-pendekatan-dan-teknik-pembelajaran/. 2012

[4] Husein, H. A. Penerapan model Discovery Learning berbantuan MMI terhadap peningkatan hasil belajar ranah kognitif pada Mata Pelajaran Teknologi Informasi dan Komunikasi (TIK). Skripsi pada FPMIPA UPI Bandung : Tidak diterbitkan. 2013.

[5] Kemendikbud. Materi pelatihan implementasi Kurikulum 2013Matematika SMP. Jakarta : Kemendikbud. 2014.

[6] Matlin, M.W. Cognition. USA: John Wiley \& Sons. 2012.

[7] Martin, S. Measuring cognitive load and cognition: metrics for technology enhanced learning. Educational Research and Evaluation: An International Journal on Theory and Practice, 20(7-8), 592-621. 2014

[8] Mayer, R. E. Multimedia learning-prinsip-prinsip dan aplikasi. Surabaya : ITS Press. 2009

[9] Paas, F., \& Van Merriēnboer, J. J. G. Tthe efficiency of instructional conditions : an approach to combine mental effort and performance measures. Journal : Human Factors, 35(4), p. 737-743. 1993.

[10] Pamungkas, D. R. (2014). Penerapan model Discovery Learning dan interactive demonstration dalam meningkatkan hasil belajar fisika siswa SMA. Skripsi pada FPMIPA UPI Bandung : Tidak diterbitkan

[11] Pappas, C. Cognitive Load Theory and Instructional Design. [Online]. Diakses dari http://elearningindustry.com/cognitive-load-theory-andinstructional-design. 2014.

[12] Retnowati, E. Keterbatasan memori dan implikasinya dalam mendesain metode pembelajaran Matematika.[Online]. Diakses dari http://eprints.uny.ac.id/6895/1/P-

1\%20Pendidikan\%20\%28Adi\%20Nur\%29.pdf 